\title{
Research on the Innovative Practice of "The Flipped Classroom" in the Basic Management Course of Chinese Universities
}

\author{
Min Li \\ School of Business, Henan University, Kaifeng, China \\ Email:1mncee@163.com
}

How to cite this paper: Li, M. (2017). Research on the Innovative Practice of "The Flipped Classroom" in the Basic Management Course of Chinese Universities. Creative Education, 8, 2155-2163. https://doi.org/10.4236/ce.2017.813146

Received: April 24, 2017

Accepted: October 28, 2017

Published: October 31, 2017

Copyright $\odot 2017$ by author and Scientific Research Publishing Inc. This work is licensed under the Creative Commons Attribution International License (CC BY 4.0).

http://creativecommons.org/licenses/by/4.0/

\section{(c) (i) Open Access}

\begin{abstract}
With the advancement of times and development of technology, the traditional teaching mode has gradually revealed some drawbacks. Therefore, a new teaching mode is needed. Flipped class, as one of the new teaching modes which can improve the students' initiative and self-discipline, has attracted colleges and universities' attention and exploration. Based on the teaching reform practice of the flipped classroom teaching mode of the basic management course in universities, this paper elaborates the significance and current situation of the flipped classroom practice in universities, and explores the specific schemes, procedures as well as the future development direction of the flipped classroom teaching mode of the basic management course. Through the analysis of these problems, we hope to contribute to the reform of flipped class teaching mode in universities, and provide some references for later research.
\end{abstract}

\section{Keywords}

The Flipped Classroom, University, The Basic Management Courses, Reform in Education

\section{The Significance of the Flipped Classroom in the Basic Management Courses}

In 2000, the Ministry of Education proposed "deepen the educational reform to promote the quality of education in an all-round way". Over the past ten years, the reform of higher education has made some achievements. However, undergraduate teaching mode reform is still mainly focused on the adjustment of the teachers and professional course structure. The basic teaching process is less in- 
volved. The arrangement of pre-class, class and post-class teaching sequence has remained unchanged. On the one hand, this paradigm has its significance, such as teachers' better mastery for knowledge which can ensure the learning efficiency of students. However, on the other hand, with the development of the times and technology, the traditional class teaching mode also revealed its drawbacks. For example, the students can't teach each other and all students have to have the same course. In addition, the students are only the receivers of knowledge but not active participants. It will results in learning deficiency if the students do not seriously accept the words. In order to solve this problem, there is a new class teaching model: the flipped classroom. The transposition of the class teaching mode is "to carry out the teaching or learning activities after class, and to discuss and answer questions in class". It was originally carried out as a kind of new class teaching practice in primary and secondary schools. Because it has ability to develop students' autonomous learning ability and improve the innovation ability, and these abilities are crucial to college students. Therefore this kind of classroom teaching mode soon gets the attention in universities. The survey conducted by the United States in 2013 shows that it has been carried out in many universities. And it can effectively mobilize the enthusiasm of students to take the initiative to learn, so that the teachers have the opportunity to grasp the ability of each student and enhance students' degree of participation in class teaching. It has achieved good results in the implementation of university teaching (Morris \& Brown, 2013).

Because the reform of teaching mode has important value, it is also the hot teaching spot in universities, but it is only practiced in small class. The basic management courses are very important courses of universities for they are the main learning contents of management majors. The basic management courses generally have many theories, such as the compact lesson time, the heavy task and the huge number of students and so on. It puts forward higher requirements to use the flipped classroom teaching model. Whether using the flipped classroom teaching mode in the basic management courses or not directly determines the implementation feasibility in the university. It also determines whether it can improve the management majors' autonomous learning ability and innovative thinking ability. However, the reality is that it is less practiced in the basic management course.

In order to solve these problems, we appeal to the university we are in to carry out this teaching reform research in 2005, which is summarized in early 2017 and ended in June 2017. Through the practice, we summed up the methods, the problems and the countermeasures of the implementation of the flipped classroom teaching mode in the basic management courses. For the implementation of the flipped classroom teaching model in university, we carry on a useful exploration. In particular, we execute a helpful exploration to implement the flipped classroom in all kinds of basic professional courses which have a lot of students and provide strong operability and extensive experience for the future of other researches. At the same time, through studying the advantages and dis- 
advantages of the "human resources management" the flipped classroom teaching mode, we help teaching management department in-depth thinking about how to implement the flipped classroom teaching mode. We should pay attention to what aspects in the implementation of the flipped classroom. The study has some references to the future researches about the relevant courses or teaching model (Li, 2014).

After nearly two years, the study has got valuable results. The results are presented as academic paper and research report. The academic paper main summarizes the basic process of the flipped classroom. The research report reports on the significance of the research, the main research methods, the main achievements, the main innovational spots and the application of the research. The innovation of this research has two main points. First, the research broadens the curriculum content of the implementation of the flipped class. Previous studies aimed at smaller classes. The study is based on the basic management courses "human resources management". Each class has more than 80 students in this course. Implementing the flipped classroom meets some new problems. Through this study, it provides experience for how to use the flipped class in bigger class. Second, the research broadens the classroom organization model. As a result of more students, this study tries a variety of class speculation teaching models. There are discussions, case teaching, non-leading group discussions, lectures, teacher guidance, etc. More ways mobilize students to participate in thinking and discussing.

\section{An analysis of the Flipped Classroom in Chinese University}

\subsection{The Status Quo of Teaching Practice in Universities}

At present, Chinese college classes still have big classes with a large number of students. "Full house irrigation" is still the basic pattern of university class teaching mode. According to the existing researches, there are very distinctive features of the implementation of the flipped class teaching model in Chinese universities (Miao \& Wang, 2015). The flipped classroom teaching model is still in the initial stage.

First, the teachers who implement the flipped classroom are mainly in the mature occupation period. In the survey of the flipped classroom teachers, more than half the teachers are within the range of the 30-39 years old and have taught more than 9 years. This shows that the teachers who implement the flipped classroom have richer experience and the certain sense of innovation, and hope to continue to improve the cause of progress.

Second, the motivation to implement the flipped classroom is influenced by the school, students and teachers. The school's policy and technical support, the idea of improving students' learning motivation and learning ability as well as the opportunity to become leaders of new teaching methods are the three main motivations of the teachers to implement the flipped class. 
Third, the main features of the flipped classroom are students learn homemade video before class and teachers guide the discussion in class. The homemade videos of the flipped classroom in Chinese universities have a higher proportion. On the one hand, self-made video reflects the teacher's own thinking; on the other hand, teachers can better grasp the content and easily guide the class discussion stages.

Fourth, the teachers are positive about the implementation of the flipped class, but they are puzzled about how to evaluate the effectiveness of the implementation. Teachers generally think that the flipped classroom has played a positive role in improving students' interest and self-confidence. And the flipped classroom has improved teachers' satisfaction with their work, but it also has increased their workload to design the curriculum and content. But the traditional pen and paper quantitative test method cannot accurately reflect the improvement of students' learning ability and learning initiative in the flipped class. Therefore, the design that can reflect the flipped classroom for students' self-learning ability is essential.

\subsection{The Difficulties Encountered in the Flipped Classroom Reform}

First, the supporting system is not perfect. Because the flipped classroom is a new way of teaching exploration, managers generally hold a positive attitude towards it, and some managers even stimulate the teachers' reform such as rewarding bonuses. But for the flipped classroom, it requires the school to give the system supports such as more time, various rules and regulations. It is the first key issue in the flipped class.

Second, teachers' willingness to reform is not strong. In addition to being very self-confident, most professional teachers' willingness to reform is not strong. The main reason is teachers need to pay a great effort to engage in the design and implementation of the transferring process, but the result has a lot of uncertainties. Students' learning attitude and learning comprehension will seriously affect the implemented effect of the flipped class, but the teacher is difficult to control the students after the class. At the same time, the current evaluation method based on the results of students' pen and paper evaluation obviously is not accurate. The implemented effects of the flip classroom in improving the efficiency of students' autonomous learning and interactive communication are difficult to evaluate in the traditional way.

Third, the flipped classroom asks for better students. Before the students only need to listen carefully in the classroom, the flipped class requires students to seriously study the professional curriculum knowledge, to diligently think and to learning initiatively. Obviously, students are required to have higher capacities.

Fourth, classroom discussion and speculation require more time and ability. First of all, because the class time is limited, so it inevitably will squeeze extracurricular learning time. In order to make more students have the opportunity to participate in the discussion and speech and summary of valuable knowledge, 
the teacher needs more time even needs to use spare time. It results in negative impacts. Second, the class discussion and speculation requires students to have some communication skills. For those students with strong language skills can make full use of the discussion to get more information and learning opportunities, and for those students with poor communication skill, their classroom participation will be affected. At the same time, the flipped classroom requires teachers to have higher ability including the control of the classroom, the curriculum planning and professional quality and so on, but not all teachers have these abilities (Rong \& Peng, 2015).

\section{The Program of the Flipped Class in the Basic Management Courses}

The program includes three levels. First, the university has macro management level. The university needs to develop appropriate system or policy to support the teachers of flipped class. What's more, the university also needs to improve the supporting reform strength such as teaching management system, personnel training programs and learning achievement evaluation methods in order to facilitate the spread of class teaching mode. Universities need to strengthen publicity so that teachers and students can change their minds and identify the value of the flipped classroom teaching mode. Second, the university needs to improve the flipped classroom teachers' semester planning level. In order to carry out the renovation of class teaching mode, teachers need to do the overall comprehensive arrangements, including teaching material design, learning task arrangement, class discussion mode selection and achievement evaluation methods. Third, the university needs to arrange the teaching procedures including preclass preparation, class guidance and careful summary upgrade after-school (Zhao, 2014). The details of the reform can be summarized as follows:

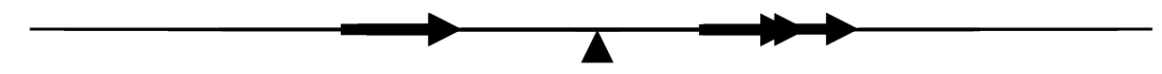

One of the key research contents is to enhance the professionalism of the flipped class in the basic management course. Students learn from each other to improve the enthusiasm and efficiency of class learning. The discussion between teachers and classmates also helps to improve the teaching quality. In addition, preparing a large number of effective learning materials will ensure that students can learn effectively after class. Apart from these, teachers should also well design the class to discuss the problem, organize the way of the course and guide the discussion. Through these designs, students' self-learning ability, thinking ability and problem-solving ability will be improved.

The research methods used in this study are mainly action research method and comparative research method. Action research method is to carry out teaching experiments with reflection and improvement. During teaching reform, we observe the student's response and teaching effect. Then we sum up the experience for continuous improvement. Specifically, the subject of the study in- 
cludes three levels: the school macro management level, the teacher semester planning level and the classroom practice level. Comparative research method is to compare and analyze the advantages and disadvantages between the classes participating in teaching reform and classes not carrying out teaching reform. This study mainly analyzes the learning interest, learning ability and learning status of the students participating in the "human resource management" flipped class. Then we contrast it with the students missing the flipped class through the teacher's observation and the students' self-evaluation. At last, we found that the students participating in the "human resource management" flipped class show more attention, more interest and more learning behaviors. But we also find out that the flipped class needs students have higher learning ability. Students also need to spend free time to learn, which increases the burden on students. About the learning results, students have similar performance in two types of teaching models, because the current examination of the course is still using the traditional pen and paper test.

\section{The Specific Procedures to the Flipped Classroom Implemented in the Basic Management Courses}

This practice of the flipped class is mainly for "human resources management" course. The project was established in 2015 and was expected to end in July 2017.

First of all, submit the reform program to the college and obtain relevant departments' support. According to the reform project, we report to college leaders and apply for the implementation of reform program. Business college leaders show great support in terms of funding, staffing, technology and lay down supporting policies to implement curriculum reform. After the launch of human resources management, professional teachers participate in the practice of the flipped class, and construct the "human resources management" reform group. Choosing "human resources management" to implement the flipped classroom reform has four reasons: (1) "Human Resource Management" is the basic management course and belongs to the general course of universities and its implementation effect is most typical; (2) "Human Resource Management" is both a liberal art course and a science course, therefore it can at the greatest extent reduce the bad effect caused by the different interest between the liberal arts and the science course in the implementation of the flipped classroom; (3) Teachers with higher education level of "Human resources management" course, who are relatively young and whose occupation is in rising, are willing to participate in the exploration of emerging teaching model; (4) "human resources management" course curriculum construction is relatively perfect and video, courseware and case library have abundant resources to help to smoothly carry out the flipped classroom reform of the "human resources management".

Second, hold several relevant teacher seminars to unite plans and actions. The teachers of the "Human Resource Management" reform group get on many seminars. The main contents include teachers' division, the specific implementa- 
tion of the plan and each lesson schedule, material collection and screening, the training to students, and so on. Through these seminars, teachers formed unified thinking and action to improve the ability to implement the flipped class.

Third, promote the teaching arrangements actively and steadily. At the first class, the teacher informs students of the new teaching mode of the lesson and the ability and learning attitude requirements, and gives students the first chapter of learning materials, including video, courseware, bibliography and learning contents which are required for students to master. At the same time, ask students to study hard, to think, to ask questions and prepare for class discussion after class. At the second class, the teacher introduces and summaries the first chapter of the course, and then asks students to answer some questions. According to the result of answering question, teachers can understand the effect of learning after class. And then let students discuss the questions which are controversial or can't accurately be answered. When the students are discussing, the teacher should guide the discussion process in time, especially difficulty and student participation and encourage as many students as possible to speak or carry out the discussion in group so that students have a deeper understanding of the issues that are being discussed. The teacher controls the rhythm of the class, the content of the discussion or comment. Finally, the teacher arranges the content of the next chapter (Zhu, Guan, \& Qiu, 2015). It should be noted that, because the students initial contact with the flipped classroom teaching method, they perhaps will find that the problems are poorly solved. So, sometimes they will remain silent after the teacher's questioning. At this time in order to ensure the quality of teaching, teachers need to guide students to answer these core issues. And in the latter part of the course students are more adapted to the flipped classroom teaching method, they will tend to take the initiative to ask questions and eager to communicate with other students. Teachers only need to filter these questions or ensure that the core issues can be discussed. At this time the teacher's main task is to control the students' discussion and class rhythm.

Fourth, summarize the problems and improve measures timely. The reform lasts for a school year. The teachers summarize the questions and solutions in time after the end of each semester. These questions include: whether the pre-class materials provided to students are reasonable and sufficient, whether the guidance to the students' discussion is appropriate, whether students really learn the knowledge and how to have better learning results. Through communication, the teachers put forward a lot of valuable opinions on the implementation of the flipped classroom of "Human Resource Management" and form a new optimized design.

\section{The Improving Direction of the Application of Flipped Class in the Basic Management Course}

After a year of practicing, it has made some valuable results. Teachers and students also consider the flipped classroom in "human resources management" a 
good thing and it improves students' learning autonomy and learning ability. But we need to know that the flipped classroom teaching mode still has some defects. Solving these problems has also become the direction of our future reform in the flipped classroom.

First, the school should increase support for the reform of the flipped class teaching mode. These supports include both the university's support regulations, funding and technical for educational reform, as well as giving a certain degree of tilt in order to encourage more teachers to participate. At the same time, the managers should establish a scientific evaluation system to the flipped classroom, including evaluation tools, scoring standards, operational processes and so on. The scientific evaluation system will play a key role in stimulating teachers and students to participate in the implementation of the flipped classroom.

Second, improve the confidence of the teachers and students to implement the flipped classroom. For a long time teachers have been accustomed to the full control of the class and knowledge, and students are also accustomed to be controlled by the teachers. The flipped classroom teaching mode will break the sense of control. Students learn the knowledge after class, and the teacher guides students to discuss questions and answers in class. During the process, teachers are worried about whether students can consciously learn and how to guide the students to discuss, while simultaneously students also have a variety of concerns. Through theoretical training and the observation of the flipped class practice, teachers and students can improve the confidence in the implementation of the flipped classroom and master the way to overcome difficulties.

Third, improve teachers' ability to implement the flipped class teaching mode. These abilities include professional knowledge and the profound explanation and opinion exchange in the class discussion on the professional issues. As for professional knowledge, it includes the preparation of teaching materials, such as literature, course ware, linking knowledge, video and so on. These abilities can promote students to understand and master the knowledge. Meanwhile, the teacher also has the ability to control the class, communication and interaction. Besides, these abilities can also help to mobilize the enthusiasm of students to discuss, improve the depth of discussion and bring about a wider range of participation.

Fourth, improve the ability of the students to participate in the flipped classroom. It needs students to take the initiative to learn independently and to think cautiously with strong self-discipline in the flipped classroom. Many students are accustomed to receive the knowledge without thinking which leads to their lack of in-depth thinking ability. Some students can't even consciously study after class, which will cause that no questions are put forward while discussing. The consequence is that students' learning is ineffective. At the same time, it requires students to have some skills of communication and interaction so that the students can fully explain their doubts and views in the discussion. These are the skills and abilities that students need to have when they implement the flipped 
class teaching mode.

Fifth, achieve the optimization of the curriculum design of the flipped class. The flipped classroom has some requirements not only for teachers and students, but also on the curriculum. The number of students to the flipped class cannot be not too many, otherwise it will affect the participation of students and result in free rider situation. The flipped classroom curriculum is suitable for theoretical study courses but not for the practical experimental courses.

\section{Conclusion}

As an effective teaching model to improve students' autonomous learning ability, the flipped classroom has been widely acknowledged. However, there is still a large load of work to do in order to achieve good results. In particular, there are still many problems in the reform of the flipped classroom teaching mode in the basic management courses because of its large students population, splendid course contents and high design standards. It is hoped that this study is valuable in the future practice of the flipped class in universities.

\section{References}

Li, Y. (2014). The Rational Thinking of Popularity of "Flipped Classroom" in China. Curriculum, Teaching Material and Method, 10, 18-23.

Miao, J. M., \& Wang, Q. (2015). Preliminary Findings on the Flipped Classroom Pedagogy: A Survey in Chinese Higher Education. Open Education Research, 21, 74-82.

Morris, J., \& Brown, S. (2013). The Up Side of Upside Down: National CDE Study Shows Flipped Classrooms Are on the Rise. http://www.sonicfoundry.com/FlippedWebinar

Rong, M., \& Peng, X. H. (2015). A Study on the History, Current Situation and Application of "Flipped Classroom". China Educational Technology, 7, 108-115.

Zhao, X. L. (2014). The Design of Teaching Mode Based on Knowledge Construction in Flipped Classroom. Modern Distance Education Research, 2, 55-60.

Zhu, Z.T., Guan, J.Q., \& Qiu, H. X. (2015). Practice and Reflection on the Application of the Flipped Classroom in China. E-Education Research, 6, 66-72. 